\title{
Transnational marriages in the north: Legal issues of Russian women married to Norwegian men
}

Hege Brækhus ${ }^{1}$

Uit The Arctic University of Norway, Tromsø, Norway.

\begin{abstract}
This article is about the legal situation for the many women who immigrated to the northernmost county in Norway, Finnmark, from North-West of Russia after the fall of the Iron Curtain. Their way of immigration was mostly through marriage to Norwegian men. To be foreign and new in a country could be difficult. How is their legal situation as newcomers? The complexity of problems will increase if they get children, divorce or move from Norway to Russia or the other way. Which authorities are to decide for them and which country's laws are to be applied? The article also covers the legal situation for children born in such marriages such as status, custody, support and child abduction, and the situation when one of the spouses dies.
\end{abstract}

Keywords: International private law, marriage, equality, immigration

\section{Introduction: Choice of Spouses and Laws at the "Top of the World"}

Finnmark, the northernmost county in Norway, shares a border with Russia. This border was strictly closed during the Cold War, but after the fall of the Iron Curtain in the early 1990s, it was opened to some extent, and those living in Finnmark became able to get in contact with their neighbors in the northwest of Russia. This has influenced the relationship between the two countries in many ways, among them in relation to immigration.

In the early 1990s, the Finnmark-Russia border represented one of the deepest welfare divides in the world. In the post-Soviet society, there were periods when workers were not paid and had to live with shortages of daily necessities (Flemmen and Lotherington 2009, 33). Although cross-border immigration was to be expected under these circumstances, it quickly became controversial. The first issue to erupt was community reactions in

${ }^{1}$ Corresponding author. Address: Hege Brækhus, Uit The Arctic University of Norway, 9037 TROMS $\emptyset$, Norway. Email: hege.brakhus@uit.no 
Norway to Russian women crossing the border allegedly to offer prostitution services in the sparsely populated areas of Finnmark. This was more than these communities could bear, according to some newspapers (Flemmen 2009, 39). The owner of a camping site was even convicted of procuration in the Supreme Court. ${ }^{2}$ Many of the women, however, could be described as "nonprofessionals;" some were housewives trying to make ends meet, others were looking for Norwegian husbands (Flemmen 2009, 45).

Given the realities of the time and place, marriage clearly offered women a more secure way to move across this border. By 2008, 1.54 percent of the population in Finnmark was found to be Russians, 82 percent of the Russian immigrants to Finnmark were women, and most women had obtained their resident permits through marriage to Norwegian men (Kvidal, Lie and Nygaard 2008).

This gender-specific form of immigration appears to be motivated by differences in gender roles of both men and women on both sides of the Finnmark-Russian border, with Russian women seeking Norwegian men whose attitudes toward gender roles are more modern than Russian men's, while at the same time significant numbers of Norwegian men seeking Russian women whom they think have more traditional views of marriage and gender roles than Norwegian women (Flemmen and Lotherington 2009, 33). Age and economic imbalances may also be factors. Divorce decisions in five appeal cases and one county level case where age was mentioned, showed an age gaps on average of 15.75 years. The average Norwegian age gap is three years.

Even if the situation for people in Russia has improved substantially since the early 1990s, there are still huge political, cultural, and economic divides between Norway and its large neighbor in the north, Russia. Emerging research has begun to examine how Russian wives cope with these differences, especially with regard to gender roles (see Kukarenko in this special issue). In general, the Russian wives appreciate their Norwegian husbands' participation in parenting their children, but expectations of gender equality mean that gender roles are uncertain and have to be negotiated with Norwegian husbands. Norwegian society in general also have different normative expectations, such as shorter periods of leave from paid work after giving birth than is common in Russia (Lotherington 2009).

In addition to cultural and normative complications, legal regulation of family life in these trans-border marriages is exceedingly complex. Some couples marry in Russia, live there for several years, and then move to Norway. Which laws regulate their relationship? Other couples married in

\footnotetext{
${ }^{2}$ See decision from the Supreme Court in Rt-2004-331.
} 
Russia have children who will go with them from Russia to their new homeland. Alternatively, they may have children born in Norway but want to move with them back to Russia upon divorce or bereavement. Can they take their children with them? In addition, what are divorcing parents' economic rights in such a situation?

International private law principles regulate choice of the courts in which such issues are decided and the laws that courts apply in relation to transnational questions. Family law is subject to these international private law principles. Norwegian courts or administrative bodies ${ }^{3}$ are authorized or have the jurisdiction in cases where the connection to Norway is sufficiently close. The question then becomes how they are to determine when that connection to Norway is close enough. Even if Norwegian courts are authorized to hear a specific case, the choice of law principles may nonetheless determine that a court must apply the law of the country in which the couple have the most connections. As a practical matter, it is very challenging for a court in one country to apply the law of another country correctly. However, there is a tendency for Norwegian courts to choose to apply Norwegian law and not Russian law; even if on the facts of the case there might be good arguments for use of Russian law. Unfortunately, international private family law cases do not produce uniform approaches to any of these choice of law issues. The jurisprudence of each country will be unique. This article is about how Norwegian international law regulates international marriages. If a parallel situation has to be resolved in Russia, then Russian international family law would be applied, but that is outside the scope of this analysis.

Questions of legal regulation of Norwegian-Russian marriages are of great importance for the families concerned, and, especially in cases concerning children, the outcome of specific cases can be dependent on cooperation between the two countries. How is child custody determined in both countries? Do they follow the principle of the best interests of the child, or do they priories the best interests of the parent who is a citizen of that country? To regulate this, international bodies have worked out international conventions or treaties, which adds another layer of legal issues to the determination of the overall rights and obligations of courts in each country. ${ }^{4}$ This article will present family law in a broad sense, because it will include not just decisions on issues occasioned by separation or

\footnotetext{
${ }^{3}$ In addition to the courts, the county administration is authorized to make decisions in most family cases in Norway, which in general is a cheaper and faster track in such cases. See Marriage Act, 1991, § 25a.

${ }^{4}$ See e.g. the European Convention on Recognition and Enforcement of Decisions concerning Custody of Children and on Restoration of Custody of Children, 20 May 1980, ETS 105 [Convention on Custody of Children], and the Hauge Convention on the Civil Aspects of International Child Abduction [International Child Abduction], 25 October 1980, 1343 UNTS 89.
} 
divorce, but encompasses children's law more generally, included inheritance and succession rights.

The cases considered in this article include reported and unreported decisions from Norway generally and from district courts in Finnmark specifically. The main focus of this article is thus on the impact of family law on Russian women who have moved to Norway and married Norwegian men. This begins with choice of law for determining the validity of marriages, and includes detailed consideration of rights and obligations pertaining to marriage, divorce, legal parental status, child custody, and inheritance or succession rights to matrimonial property.

\section{Validity and Economic Rights of Marriage}

The practice of traveling abroad to marry is well established in modern life. Couples travel, for example, to places like Las Vegas and expect to be able to marry there even if neither party is a citizen or resident of either the United States or Nevada. No doubt couples from abroad travel to Norway or happen to decide to get married while in Norway. In Norwegian law as in other countries, marriages are valid regardless of where they are contracted so long as the jurisdiction in which the marriage is performed permits such marriages under its own laws.

As a general principle of private international law, being married is an incident of personal status that they carry with them wherever they are. Domestic laws can restrict that capacity to get married for specific policy reasons. For example, Norwegian marriage law was amended in 1994 to forbid marriages involving a party who is in the country illegally. ${ }^{5}$ This was done because being married is an argument for staying in Norway.

Most women who move to Norway from Russia immigrate through marriage. Until 2010, even marriages motivated purely by the desire to immigrate to Norway were perfectly valid, even if the parties never intended to live together and agreed to divorce as soon as possible. ${ }^{6}$ After 2010, the Immigration Act prohibited entry into Norway if the only reason for marrying was immigration. ${ }^{7}$

It is important that the marriage is also valid according to the law of the country from which the parties have come and to which they often may intend to return. For this reason, two or three legal regimes have to be considered before a marriage is performed in Norway - the Norwegian legal requirements, and the conditions for validity of marriage according to the

\footnotetext{
${ }^{5}$ See Marriage Act, $\$ 5$ a.

${ }^{6}$ In an old case before the Supreme Court a Russian baroness paid to marry a Norwegian man just to get

Norwegian citizenship. According to the Supreme Court the marriage was valid. See Rt-1926-426.

${ }^{7}$ Immigration Act, 2008, as amended, § 40(4).
} 
laws of each of spouses' homelands. ${ }^{8}$ If, for example, it is prohibited for second cousins to marry in one party's country, the Norwegian authority should not permit second cousins to marry in Norway even if such marriages are allowed in Norway. The same is true of age; the couple has to be old enough to marry in each of their home countries as well as in Norway. ${ }^{9}$ On the other hand, if a marriage performed in another country is sought to be recognized in Norway, it must be formally valid in the country in which it was performed, and must not be contrary to Ordre public in Norway. ${ }^{10}$

Couples marrying in Norway must also follow the formalities of Norwegian law. It is increasingly recognized in Norway that legal obligations by spouses to support each other economically create dependence on the part of the spouse receiving support thus contravene the idea of equality between spouses. ${ }^{11}$ However, in Norwegian law, as long as a couple lives in Norway, Norwegian law regulates their right to support, and spouses still do have the formal legal obligation to provide economic support to each other. Unfortunately, the support rules are not very specific. It is understood that this obligation requires something more than providing bare subsistence support, but what that might mean in any specific relationship is not clear. ${ }^{12}$ In practice, there is no way to enforce this right if the husband does not want to comply. For this reason, most Norwegian women choose to have an income of their own.

For Russian wives entering Norway, the Norwegian spouse has to guarantee to provide economic support for three years. Only after that period can non-Norwegian spouses obtain permanent residence and work permits. ${ }^{13}$ During that three-year period, the sponsoring spouse has to guarantee to provide support. One of the complexities of this provision is that during this period of time, immigrating spouses, particularly women, are more vulnerable to economic domination, emotional abuse, and physical violence by the sponsoring spouse. The situation may be surprisingly poor for these women because matrimonial property law in Russia is much more equal as between spouses. In Russia, all property,

\footnotetext{
${ }^{8}$ Marriage Act, § 7(h).

${ }^{9}$ Of less interest in the Norwegian-Russian marriages is that Norway does not recognize forced marriages even if this is common in the spouse's home country. This is because of the general rule in international private law called Ordre public. Ordre public is a general standard in international private law. The standard allows exceptions from the general solutions derived from international private law if the solution will contravene the moral standards of the country.

${ }^{10}$ Thus, Norway will not approve bigamy or payment for the bride. To deny marriage for religious reasons or because of divorce will also be contrary to Norwegian Ordre public.

${ }^{11}$ See "Innstilling til ny ekteskapslov del II [Recommends new Marriage Act, Part II]," Norges Offlentige

Utredninger [Official Norwegian Reports], 30 (1987): 32.

${ }^{12}$ See Marriage Act, $\$ 38$.

${ }^{13}$ See Immigration Act, \$§ 55(1), 60(1) and 62(1).
} 
including income acquired by one spouse during the marriage, is the couple's joint property. ${ }^{14}$

However, property rights are not normally the main concern of women during the first three year of marriage, because if they are divorced within these three years, they have to leave Norway and return to Russia. ${ }^{15}$ In the light of these considerations, it appears that the Norwegian government continues to use immigration and spousal support rules to avoid its economic obligations to financially distressed women. Many Russian wives are well educated and qualified for work, and, after obtaining permanent residence in Norway, they are supporting themselves through paid work (Flemmen and Lotherington [eds.]. 2009, 101).

Marital property rights are also complicated in Norwegian-Russian marriages. Most countries have special rules concerning property ownership rights during or arising from marriage. Norway is no exception, although marital property rules have become less constraining than in the past ${ }^{16}$ However, the rules are more complicated for cross-border marriages. Basically, property rights follow the law in the country the couple first lived in after marriage (Thue 2002, 398). ${ }^{17}$ This is because it was probably under the premises of this law that they first entered into marriage. If their first domicile was Russia, their rights concerning property will be determined by Russian law even if they move to Norway. And, if they first lived in Norway, their property rights will be governed by Norwegian law even if they move to Russia.

One common question is whether a couple married and living under the matrimonial property law rules e.g. of Russia and then moves to Norway can agree that they will be governed by Norwegian property law instead of by Russian property law. This question has been discussed quite extensively in Norwegian international family law (Thue 2002, 423-428). The most reasonable answer seems to be that if both spouses agree to this change in matrimonial property regimes, and if they both have the proper connection to the country whose system they choose, they can do so (Holmøy and Lødrup 2009, 159). The agreement ought to be formally correct in ensuring that the spouses make legally effective agreements under the law. The law concerning property rights also determines the validity of contracts made by spouses. In Norway, the rules for such contacts are spelled out in the Marriage Act. ${ }^{18}$

\footnotetext{
${ }^{14}$ See Family Code of the Russian Federation, 1995, arts 33-34.

${ }^{15}$ There is an exception from this if they have been exposed to violence, but this of course may not be easy to prove, especially if the spouse has no other immediate sources of support. Immigration Act, regulation, \$11(4)(c).

${ }^{16}$ The main effect of these property rights is however upon divorce, see below.

${ }^{17}$ See also Rt-1995-1415.

${ }^{18}$ See Marriage Act, $\$ 54$.
} 
Not surprisingly, however, there are exceptions to the situation in which all property rights are governed by the system of one country. If third parties such as creditors have claims against either spouse, then the law of the country of the third parties' residence should apply even if the spouse or spouses owing the obligation are subject to the laws of a different country. Creditors cannot be required to seek remedies under foreign legal systems with which they are not familiar (Thue 2002, 407).

Other exceptions apply to the legal basis for the recognition of marital property rights. In Norway, spouses can acquire property rights in property owned by the other spouse through performing unpaid childcare and housework. ${ }^{19}$ As long as the couple lives in Norway, property can be earned this way regardless of which laws may apply more generally to their marital property rights (Thue 2002, 409).

If the couples legal system is Norwegian law, the fundamental principle to ownership are individual rights, which means that married persons' earned property remains individual property. ${ }^{20}$ Thus, if the couple moves into a home in which one of them has lived for many years prior to the marriage that person retains ownership of the home despite the fact of the marriage.

\section{Divorce, Alimony, and Property Rights}

If a divorcing couple has been residing in Norway, then Norwegian laws and procedures apply. Even if only one spouse lives in Norway, or if both spouses are Norwegian citizens living elsewhere, Norwegian courts can accept the petition for divorce. Norwegian courts also have jurisdictional authority to hear petitions in cases in which one spouse has only a slight connection with Norway but divorce would for some reason be difficult to obtain in the couple's country of residence. ${ }^{21}$ If couples living in another country are divorced there, Norway will acknowledge the validity of that divorce if the parties had sufficient connection with that country at the time the decision was made. ${ }^{22}$

If the parties want to remarry, foreign divorce decrees must be domesticated by the correct Norwegian authority. The State Department is entitled to decide on this issue. ${ }^{23}$ The authority to make such determinations is delegated to County Governors. ${ }^{24}$ The County Governor will not in general acknowledge private agreements about divorce; these have to be decided

\footnotetext{
${ }^{19}$ See Marriage Act, $\$ 31(3)$.

${ }^{20}$ See Marriage Act, $\$ 31(1)$.

${ }^{21}$ See Marriage Act, $\$ 30(\mathrm{~b})$.

${ }^{22}$ See Act on Recognition of Foreign Divorces and Separations, 1978, § 1 .

${ }^{23}$ See Act on Recognition of Foreign Divorces and Separations, $\$ 4$.

${ }^{24}$ See Regulation March 27, 1992, nr. 292.
} 
by the authorities in the country concerned. Any such proceedings also have to be fair, give both parties the right to be heard, and treat both parties consistent with gender equality. For Russian divorces, registration in the Russian register for civil status, the ZAGS, is generally the proof required. ${ }^{25}$

The legal regime that regulates a couple's property rights will also regulate the settlement of property rights on divorce. In Norway, the general rule is that the value of communal property earned during the marriage is divided equally between the spouses, meaning that property owned on entering into marriage can be kept out of the division. ${ }^{26}$ Property kept separate according to a marriage agreement, gifts, and inheritances acquired during the marriage are also exempted from the property to be divided. ${ }^{27}$ Creditors' rights that is still governed by the law of the country where the debts were established in the case of divorce, even if the property rights are governed by the law of another jurisdiction. Consequently, in the division of property upon divorce, it is important that creditors' claims are treated in accordance with the law of the country in which the debts were established.

We have seen that spouses remain individual owners of their own property acquired before or during marriage. On divorce each spouse does have a right to keep those specific items of property each owned during the marriage. There are some exceptions to this rule, however, with reference to the family home and necessary equipment and furniture in the home. ${ }^{28}$ The rule here is that either title or use rights to the family home can be awarded to the spouse who will have the day to day care of the children. However, the main asset in most marriages is the family home, and may have depended on two incomes to support this asset. Thus maintenance of the family home may be too expensive for one parent to afford, particularly if ownership or rental rights are awarded to the wife. The award of use or ownership of the family home is treated as a right granted on social grounds like the award of alimony (see below) under the law that applies to the location and use of the property. This jurisdiction may differ from the jurisdiction in which the rest of the couples' property rights will be decided. Household effects for everyday use will be treated as subject to the same rules applying to the house itself.

In almost all the cases concerning Russian-Norwegian marriages, the husband already owned the common family home before the marriage took place. In these marriages, the husband was considerably older than the Russian wife and was well established in the local community. The wife on the other hand was a foreigner, probably without much property of her

\footnotetext{
${ }^{25}$ See Directive Q-19/2004, appendix 5.

${ }^{26}$ See Marriage Act, \$\$ 58-59.

${ }^{27}$ See Marriage Act, $\$ \$ 42(1)$ and 59.

${ }^{28}$ See Marriage Act, \$§ 66-68.
} 
own. When the family home is owned by the husband before marriage, its value is not divided between the spouses on divorce. This makes it very difficult for the wife to buy out the husband.

The imbalance between husbands and wives in claims to the family home are illustrated in several cases before the Court of Appeal, Hålogaland lagmannsrett, and County Courts, Øst-Finnmark tingrett and Indre Finnmark tingrett. In each case, the husband was awarded the right to take over the common home after divorce. ${ }^{29}$ In one of the appellate cases, the husband's right to the home was contested, but the judgment was in the husband's favor. ${ }^{30}$ All these couples had one child together; the father was awarded custody in only one of the cases before the Appeal Court ${ }^{31}$ and in both cases in the County Courts. The right of the parent with custody for the child to keep the family home seems not to have been followed in these cases. Russian wives face many challenges in Norway as foreigners, and not having equal rights to the use of the family home upon divorce - especially when having custody of a child - means that upon divorce, they need to move themselves and any children out and find a new home. ${ }^{32}$

Rights to support after divorce proceed on different principles than are applied to distribution of matrimonial property rights. Support rights or alimony will be awarded on the basis of social and actual economic needs. Social and economic needs will differ from country to country, because they will be affected by access to and costs of childcare facilities, social systems, labor market opportunities, and other diverse factors. From a legal perspective, Norwegian international law states that support after divorce should be determined under the law of the country in which the person in need lives (Thue 2002, 388). This means that if a Russian woman returns to Russia after divorce from a Norwegian man, it is Russian law that will determine whether or not she is entitled to alimony - even if the decision is to be made by a Norwegian court.

\section{Parents and Children: Status, Custody, Support, and Abduction}

Almost all countries adhere to the ancient rule that the husband of the woman giving birth is the father of the child. Norwegian international family law recognizes fatherhood decided abroad on this basis. ${ }^{33}$ The only question

\footnotetext{
${ }^{29}$ See LH-2001-1034, LH-2001-1079, LH-2005-174121, LH-2005-47480, LH-2006-73627, 10-169137TVI-OSFI and 06068019TVI-INFI.

${ }^{30}$ See LH-2005-174121.

${ }^{31}$ See ibid.

${ }^{32}$ One case was different in the sense that the Norwegian man had formally transferred the property to his Russian partner with whom he had a child. He later claimed that this was done only to keep creditors away, but the court did not accept this explanation. See LH-2000-429.

${ }^{33}$ Children Act, 1981, § 85(1).
} 
that can occur in this situation is whether or not the marriage is valid. Beyond this, Norwegian authorities can make determinations of paternal status on the basis of Norwegian law, if the child lives in Norway and the guardian of the child (in most cases the mother) wishes it. This is also the case if a putative father lives in Norway and the mother lived in Norway when the child was born. ${ }^{34}$

When questions of fatherhood are determined outside Nordic countries on the basis of facts other than the existence marriage, the validity in Norway of such a decision has to be decided on a case by case basis by Norwegian authorities. In general, Norway will recognize determinations of paternity made outside the Nordic countries as valid if it is made by a competent public body. ${ }^{35}$ Acquisition of parental status by adoption is decided on international legal principles. In general, a Norwegian couple adopting a child from abroad has to meet all the requirements of Norwegian law. In addition, the child's status will also depend on whether all the legal requirements pertaining to adoption in the child's homeland are satisfied correctly.

Once parental status is established in relation to a child, then each parent has full parental responsibility in relation to the child. In Norwegian law, parental responsibility is the legal concept that gives parents the right to make decisions in relation to their children regardless of where the children live. Parental responsibility differs from the legal concept of custody, which is concerned with the parent who has day-to-day care of the children. ${ }^{36}$ Parents with parental responsibilities have to take care of the child and raise it according to its needs and abilities. The use of physical aggression and punishment are strictly forbidden to parents and other caregivers. ${ }^{37}$ For children living in Norway, Norwegian law regulates the terms of parental responsibility even if one or both parents are from another country, the child is born abroad, or parental status has been established under the law of another country such as Russia.

According to Norwegian law, both parents have parental responsibility for their children as long as they are married or live together ${ }^{38}$ If the parents separate or divorce, both continue to have the full rights and obligations of parental responsibility until legal authorities decide otherwise. In most cases in which custody is disputed, the nonresident parent retains parental

\footnotetext{
${ }^{34}$ ibid, \$\$ 81(1) and 84 .

${ }^{35} \mathrm{ibid}, \$ 85(2)$. The law says that the King decides either by general administrative regulation or on a case by case

basis. The case by case decision is delegated to the Norwegian Labor and Welfare Service, per Ministry for

Children, Equality, and Social Inclusion, Letter to the Norwegian Labor and Welfare Service (Mar. 30, 2011).

(NAV).

${ }^{36}$ Children Act, $\$ \$ 30$ and 36.

${ }^{37}$ Children Act, $\$ 30$.

${ }^{38}$ Children Act, $\$ \S 34$ and 35(2).
} 
responsibility. ${ }^{39} \mathrm{~A}$ father with parental responsibility can forbid his children to move abroad even if the mother has custody of them..$^{40}$ If, in spite of this, the mother does move with the children to another country such as Russia, this act is considered to constitute child abduction. In contrast, if the parents never lived together or if there is a decision saying that only the mother has parental responsibility, she could move with the children wherever she would like. ${ }^{41}$

A parent can also be excluded from parental responsibility if the parties were married or lived together in another country where parental responsibility does not exist or is not shared after parental separation or divorce. In a County Court, Øst-Finnmark tingrett case, the parents had lived together in Russia and then the father moved to Norway. He sued the mother for shared parental responsibility but the Court found that the level of conflict was high and refused to support the father's claim..$^{42}$ The opposite situation can also occur. If a Russian wife is divorced from a former Russian husband and wants to take the children with her to Norway, the father with parental responsibility has the right to prevent his children from moving abroad even if the mother has custody. This was the situation for a Russian mother who married a man in Finnmark. The Norwegian Directorate of Immigration denied her son permanent residence because his Russian father had not approved the boy's moving to Norway. Oslo City Court deals with such cases and found the Directorate's decision invalid according to the European Convention on Human Rights, article 8, the right to family life. ${ }^{43}$

Jurisdictional disputes on parental responsibility or custody are subject Norwegian law if either the defendant in the case or the child live in Norway ${ }^{44}$ This rule has been criticized because under the general rules of international law, courts or administrative bodies in the country where the child has its habitual residence have jurisdiction over these issues. This rule is considered to be in the best interests of the child, because it makes it easier for courts and investigative authorities to obtain accurate and full information on the wishes of the child and the adequacy of its living conditions (Kvisberg 2008, 79).

If the mother has returned to Russia after divorce and taken the children with her without the consent of the father, it may be a question of child abduction. If that is the situation, the children should be returned, and while away, will still have their habitual residence in Norway. If the child is

\footnotetext{
${ }^{39}$ Children Act, $\$ 34$.

${ }^{40}$ Children Act, $\$ 40$.

${ }^{41}$ Children Act, \$ 35(1).

${ }^{42}$ See 08-152773TVI-OSFI.

${ }^{43}$ TOSLO-2003-5175.

${ }^{44}$ Children Act, \$§ 82(1) and 84.
} 
not returned the custody case still comes under Norwegian jurisdiction and follows Norwegian law. ${ }^{45}$ However, if the child is in Russia for a long time, possibly for several years, a Russian court might consider that it has acquired jurisdiction to handle the case. In cases in which a parent has agreed to the children being moved from Norway to Russia, and if no decision was made about parental responsibility or custody before they moved, but he still wants to contest the case, he will have to do so before a Russian court. In one case heard by the County Court, Øst-Finnmark tingrett, both parents were Russians. The father had moved to Norway after divorcing. He sued the mother for joint parental responsibility, but his petition was denied. In its decision, the court did not discuss whether it had jurisdiction over this case, ${ }^{46}$ Norwegian law states that courts cannot handle such cases unless either the child or the defendant is living in Norway. In this case, neither did. This suggests that there may be an advantage to filing cases concerning parental responsibility or custody in their own country of residence.

However, international law tends to make it difficult for a parent to retrieve a child from another country. If a Russian court has made a decision about custody, the role of a Norwegian court depends on whether there is a treaty between the countries in question. The relevant conventions in these cases are the Hague Convention on the Civil Aspects of International Child Abduction and the European Convention on Recognition and Enforcement of Decisions Concerning Custody of Children and on Restoration of Custody of Children, both from 1980. Norway has ratified both; Russia has adopted the Hague Convention, but not the European Convention. There is no agreement between Norway and Russia because each country has to accept every single signatory to the treaty, and Norway has not accepted Russia, probably because of procedural weakness in the Russian implementation of the treaty. ${ }^{47}$ This means that the treaty cannot be used in these situations. Thus, a father who has a court decision in his favor or who wants to alter a Russian court decision has no recourse as long as the mother and the children stay in Russia. If the children or the mother return to Norway, however, the case can be tried again in a Norwegian court because decisions on parental responsibility and custody in general are limited regarding legal validity. According to Norwegian law, such cases can be reopened at any time if there are good reasons for doing so. ${ }^{48}$ Child custody and visiting rights are normally determined as part of divorce proceedings.

\footnotetext{
${ }^{45}$ That was the situation in a case before the County Court, Indre Finnmark tingrett, 06-068019TVI-INFI.

${ }^{46}$ See 08-152773TVI-OSFI.

${ }^{47}$ Information provided to author from the Norwegian Ministry of Foreign Affairs.

${ }^{48}$ Children Act, § 64(2).
} 
In most of the marriages between Russian women and Norwegian men, both parties will stay in Norway after the divorce and will take legal action before a Norwegian court if there is a dispute concerning custody of the children. In two out of three custody cases in the Court of Appeal, Hålogaland lagmannsrett, the Court upheld the Russian mothers' custody claims. ${ }^{49}$ In two cases before the County Courts, Øst-Finnmark tingrett and Indre Finnmark tingrett, the Norwegian father gained custody. ${ }^{50}$ In all these cases the mother had moved out of the family home, often to a more urban area. Due to age and health, all the fathers were permanently or temporarily unemployed while the mothers were active in education and work. The Russian origins of the mothers made these cases different from other cases typically heard in these courts. Some of the mothers argued that the child needed to learn the Russian language and stay in contact with their Russian family and culture. The mothers who had moved to more urban areas argued that they could offer the children leisure activities and education not available if with the father. Some also argued that the fathers were old and in bad health. Fathers emphasized their ability to offer the children stability and family relations. The courts tended to emphasized the importance of learning the Russian language, becoming comfortable with Russian culture, and staying in contact with the Russian family.

In visiting rights cases, there is a presumption in Norwegian law that visiting an absent parent is a child's right. ${ }^{11}$ Most parents make agreements about this question during divorce proceedings. ${ }^{52}$ If the parents do not agree, visiting rights can be decided by the Norwegian authorities if the defendant or the child resides in Norway. ${ }^{53}$ The decision will then follow Norwegian law. ${ }^{54}$ Thus, if a Russian mother returns to Russia after a divorce and leaves the children behind, she can be awarded visiting rights by a Norwegian court. If a Russian mother takes her children with her to Russia after a divorce and there is no agreement or decision about contact between the father and the children, a Norwegian father cannot go to a Norwegian administrative body or court to claim visiting rights; the father then has to claim visiting rights before a Russian court. ${ }^{55}$

In most cases, both parents remain in Norway after divorcing. Because mothers and fathers tend to view themselves as being able to offer the children very different qualities, courts consider that contact with the parent without custody is very important because it will supplement and complete the children's lives. Many cases decide on both custody and

\footnotetext{
${ }^{49}$ LH-2001-1034, LH-2005-47480 and LH-2006-73627.

${ }^{50} 10-169137$ TVI-OSFI and 06-068019TVI-INFI.

${ }^{51}$ Children Act, $\$ 42(1)$.

${ }^{52}$ Children Act, $\$ 43(2)$.

${ }^{53}$ Children Act, $\$ 82(1)$.

${ }^{54}$ Children Act, $\$ 84$.

${ }^{55}$ See Family Code of the Russian Federation, 1995, art 66.
} 
visiting rights in the same proceeding. ${ }^{56}$ It seems that the parents in most of the cases were in favor of extended visiting rights especially if they were successful in their custody claim. One reason could be that being in favor of the child's contact with the other parent is an argument for being awarded custody. ${ }^{57}$

Child support after divorce also falls to the same courts. If the child or one of the parents live in Norway, then the Norwegian authorities are authorized to make decisions about child support, ${ }^{58}$ and decisions will be made in accordance with Norwegian law. ${ }^{59}$ This approach differs from that taken to choice of law in deciding alimony after divorce. In alimony cases, it is the law of the country where the claimant lives that should be applied, because the needs will differ according to cost levels and the social system in place in that country. This argument will certainly apply to child support and is in accordance with Norway's international commitments through the ratification of the Hague Convention concerning maintenance obligations. ${ }^{60}$ Norwegian law is obviously in breach of this convention. This is to some extent taken into consideration. According to the preparatory works for the law, the support for a child living abroad could be less than if the child lived in Norway if the cost of living abroad is lower than in Norway. ${ }^{61}$ As a result of less generous social services in Russia, however, living expenses in Russia might easily be higher than in Norway; a situation for which the preparatory works do not provide any solution.

If children are taken out of Norway leaving behind a non-consenting parent with parental responsibility or custody, that act of moving the children is considered to be child abduction and is classified as a crime in Norwegian law. ${ }^{62}$ The important thing for the parent who remains in the country where the child used to live is, however, how to get the child returned to their country of origin.

In Norway, there is a special law governing the civil aspects of child abduction. ${ }^{63}$ Unfortunately, the relevant provisions of the law apply only to countries that have accepted the Hague Convention on child abduction. ${ }^{64}$ As discussed above, the Hague Convention does not apply in cases between Norway and Russia. Thus the relation between the two countries will then

\footnotetext{
${ }^{56}$ See LH-2001-1034, LH-2005-47480, LH-2006-73627, 06-068019TVI-INFI, 10-16913TVI-OSFI.

${ }^{57}$ In one case before the Appeal Court, Hålogaland lagmannsrett, the case was about gradually increasing visiting rights until the decided level was reached.

${ }^{58}$ See Children Act, $\$ 83(\mathrm{~b})$.

${ }^{59}$ See ibid, $\$ 84$.

${ }^{60}$ See Convention of 2 October 1973 on the Law Applicable to Maintenance Obligations [Maintenance Obligations], 2 October 1973, UNTS 209, arts 1 and 4.

61 "Lov om barn og foreldre [Act on Children and Parents]," Norges Offentlige Utredninger [Norwegian Official Reports], 35 (1977): 107.

${ }^{62}$ General Civil Penal Code, 2005, § 216.

${ }^{63}$ Child Abduction Act, 1988.

${ }^{64}$ Convention on Custody of Children, and the International Child Abduction.
} 
be treated in accordance with customary diplomatic practices. The Ministry of Foreign Affairs will assist parents in this situation with advice and contacts, enabling the entitled parent to negotiate with the abducting parent. If this is not successful, legal action in a Russian court can be the next step. During the trial in Russia, the Norwegian embassy might support the plaintiff parent. ${ }^{65}$

Such procedures are much less effective than those established under the Hague Convention procedure. This is illustrated in a case before the County Court, Indre Finnmark tingrett, ${ }^{66}$ in which both parents had parental responsibility but the Russian mother had been awarded custody by the Appeal Court. Both parents lived in Norway after the divorce, and were subject to the rule that parents are not allowed to move abroad with a child. ${ }^{67}$ Shortly after the decision from the Appeal Court, the mother nevertheless took the child with her when she moved to Russia. In response, the Norwegian court awarded custody to the father, but because no agreements existed between the two countries, enforcement could only be obtained through protracted litigation or diplomatic intervention. When there is a risk that something like this might happen in a custody or parental responsibility proceeding, Norwegian courts can order restriction of parent and child exit permits. ${ }^{68}$ In an Appeal Court decision from Hålogaland Lagmannsrett, a Norwegian father sued the Russian mother in order to obtain an exit permit restriction. The mother provided evidence that she was returning to Norway for paid work and that the child went to kindergarten there. On the basis of this evidence, the court found that there was no real danger of child abduction and thus denied the application for restriction of exit permits. ${ }^{69}$

\section{Bereavement and Spousal Inheritance}

It is a general rule in international private law that the administration and division of a deceased's estate is carried out in and follows the law of the country in which the deceased had his or her habitual residence at the time of death (Thue 2002, 510). Therefore, if a spouse has died in Norway, the Norwegian authorities are in charge and Norwegian law has to be followed. If a spouse dies while living in Russia, Russian authorities and Russian law would process the estate.

\footnotetext{
${ }^{65}$ See web document "Barnebortføring [Child Abduction]," Regjeringen [Government], https://www.regjeringen.no/no/sub/barnebortforing/id468120/ (accessed Dec. 20, 2015). Barnebortføring - regjeringen.no.

${ }^{66}$ 06-068019TVI-INFI.

${ }^{67}$ Children Act, supra note $47, \S 40$.

${ }^{68}$ ibid, $\$ 43(a)$.

${ }^{69} \mathrm{LH}-2003-24$.
} 
When a spouse dies in Norway, Norwegian law determines the inheritance, including division of the estate. Before the inheritance can be estimated, there has to be a division of the communal property between the spouses. This will be done according to the law that regulates their property rights during life, which is determined by Russian law if the couple's first permanent residence was in Russia. According to Norwegian law there is a statutory portion assigned to the deceased's children that has to be adhered to and which cannot be reduced or eliminated by will. ${ }^{70}$ From time to time, questions about fatherhood arise in relation to the settlement of the deceased's estate. The spouse of the deceased will also inherit according to Norwegian law, but here a will combined with information about it can reduce or nullify this right..$^{71}$ There is however a minimum inheritance for a spouse based on social grounds that cannot be reduced by a will and which can reduce the statutory portion for the children. ${ }^{72}$ If the spouses are divorced or legally separated at the time of death, the surviving spouse is not entitled to any inheritance or other rights connected with the death. ${ }^{73}$

In most countries, there are requirements about the form of a will required for validity. These requirements can differ from country to country. Questions about choice of law pertaining to both validity of the will and the testamentary capacity of the deceased can arise. The general rule in both cases is that the law of the country where the will is made regulates the requirements (Thue 2002, 533 and 537). According to Norwegian international law, the requirements regarding form of the will are to be found in the laws of the country in which the will was executed or where the testator was a citizen or was habitually resident. If the will involves real estate, it may also have to meet the legal requirements established by the law of the country in which the property is situated. ${ }^{74}$ For RussianNorwegian couples living in Norway, there could easily be a choice because they need not move their habitual residence to make a will according to Russian law. A visit to Russia is enough to render it valid. But this is only true about the form for the will. As the legal regulation still follows the law in the country where the deceased had her or his habitual residence at the time of death, the statutory portion for children according to Norwegian law has to be respected if the spouse dies in Norway, even if these rules were different from those governing Russian law.

According to Norwegian law, a spouse can take over communal property as an entire estate by virtue of survivorship of joint interests. This happens independent of dispositions by will. But, this will not happen if any intestate

\footnotetext{
${ }^{70}$ Inheritance Act, 1972, § 29.

${ }^{71}$ Inheritance Act, \$\$ 6-7.

${ }^{72}$ Inheritance Act, $\$ 6$.

${ }^{73}$ Inheritance Act, $\$ 8$.

${ }^{74}$ Inheritance Act, $\$ 54$.
} 
successors are children of the deceased but not of the living spouse. ${ }^{75}$ It has not been settled whether the rules concerning the matrimonial estate operate by virtue of the law of the country in which the deceased was last habitually residing, or whether it is subject to the law of the country applied in regulating the spouses' property rights (Thue 2002, 558-563). If the spouses are married and have lived in Norway throughout the marriage until the first death of either spouse in Norway, there is of course no problem. The problem occurs if the spouses' first habitual residence was in another country, such as Russia, but they had moved to Norway by the time of the death. Or the other way around; the spouses' first habitual residence was in Norway, but at the time of death they lived in Russia. The right to keep the communal property entirely is closely linked to the nature of the communal or matrimonial property. The close link supports the view that the right should follow the law of the country where the couple had their first habitual residence (Thue 2002, 562). If a surviving spouse wishes to claim the right to keep the estate undivided, this right must be claimed with 60 days after death, according to Norwegian law. ${ }^{76}$ This means that the surviving spouse has to know about this right in order to be able to benefit from it. That could be a problem if the surviving spouse is not familiar with Norwegian legal issues or has problems understanding Norwegian. That was the situation in a case before the Court of Appeal, Hålogaland lagmannsrett, where the Russian wife had brought her claim to court after the deadline for claiming an undivided estate. In that case, however, the court accepted her claim on procedural grounds. ${ }^{77}$

\section{Gender Equal Policy Recommendations}

It is not easy to move to a foreign country. Russian women who move to Norway to marry will experience all the challenges of immigration. But in addition, they will encounter gender-specific barriers that arise from the structural impact of their situation. Many of these problems could be resolved if Norway and Russia could agree to sort them out as good neighbors. This chapter concludes with some pragmatic recommendations on changes to legal policies that can produce more equitable outcomes in the future.

The vulnerability of women is most intense during the first three years they spend in Norway as sponsored wives. The nature of these challenges can be quite severe, with some concern for personal safety not admitting of easy solutions or safeguards for those charged with their security and

\footnotetext{
${ }^{75}$ Inheritance Act, $\$$ 9-10.

${ }^{76}$ Inheritance Act, $\$ 14$

${ }^{77}$ See LH-201258377.
} 
integrity. These vulnerabilities may well be exacerbated by social isolation reinforced by language, cultural, economic, or gender barriers arising from their circumstances. The biggest legal barrier to optimal integration, however, is the prohibition on work permits for three years after arrival. Economic dependency in marriage for an enforced period of three years is unreasonable, and disparately impacts women spouses immigrating to Norway. Norwegian wives can more or less opt out of this dependence and support themselves through paid work, but for Russian wives are forced into economic dependency because they cannot qualify for work permits. This result is contrary to all Norwegian standards of equality, and can easily be abused by some husbands (Lotherington and Fjørtoft 2009, 14 and 18). Most Russian wives are well educated and want to work. It should be quite easy to make a legal exception to extend temporary work permits to married immigrants both to protect the equality rights of married women and for the sake of good relations with Russia.

The second major barrier arises from the lack of bilateral agreements between Norway and Russia with respect to personal relationship issues. The border between Norway and Russia is quite open and people meet each other across it; some will find their spouse on the other side and will have children together. Norway has entered into international agreements concerning the children of transnational marriages with many foreign countries, but not with Russia. Whose responsibility this is, is an open question. There are surely challenges, but thinking of the situation for children and for ease of family life in this region of Norway in particular should be a priority.

Most parties in transnational family cases will regard it as an advantage that their case can be decided by the authorities in and according to the law of their own country. As we have seen Norwegian international family law has a preference for the application of Norwegian law to cross-border relationships and family structures. Coordination of private law regimes is however desirable in relation to matters affecting children. Most countries say that they priories the best interests of children over other considerations. Thus, in cases affecting important questions in children's lives such as those involving parental responsibility, custody, visiting rights, support, and alimony, it is important for deciding authorities to know the actual conditions under which children are living or may go to live, and, for older children, their opinions on the options in question. This might best be done if the case is heard where the children have their habitual residence, as a matter of family security as well as of coordination of conflicts of laws issues. The preference for the application of Norwegian law in most of these contexts is at odds with good practices in international relations, and 
diverges significantly from international legal norms that provide that the law of the country where the child lives should be applied in such cases. ${ }^{78}$

${ }^{78}$ Hague Conventions, Maintenance Obligations, arts 1 and 4. 


\section{References}

Flemmen, Anne Britt and Lotherington, Ann Therese (eds.). 2009. Transnational Marriage Migration: Russian-Norwegian Encounters. Saarbrücken: VDM Verlag.

Flemmen, Ann Britt. 2009. Russian women in North-Norwegian Newspapers: Minority and Majority Constructions. In Anne Britt Flemmen and Ann Therese Lotherington (eds.). Transnational Marriage Migration: Russian-Norwegian Encounters. Saarbrücken: VDM Verlag.

Holmøy, Vera and Lødrup, Peter. 2001. Ekteskapsloven [Marriage Act]. Oslo: Gyldendal Norsk Forlag.

Kvidal, Trine, Lie, Ivar and Nygaard, Vigdis. 2008. Russisk arbeidskraft i Finnmark [Russian Labour in Finmark]. Norut Notat 1001, 19-20.

Kvisberg, Torunn E. 2008. Internasjonal barnebortføring [International Child Abduction]. In Mary-Ann Hedlund (ed.). Barnerett - $i$ et internasjonalt perspektiv [Barnerett - in an international perspective]. Bergen: Fagbokforlaget.

Lotherington, Ann Therese. 2009. Beyond Borders: Construction of Gender Equality and Norwegianness. In Anne Britt Flemmen and Ann Therese Lotherington (eds.). Transnational Marriage Migration: RussianNorwegian Encounters. Saarbrücken: VDM Verlag.

Lotherington, Ann Therese and Fjørtoft, Kjersti. 2009. Capabilities and Participation. In Anne Britt Flemmen and Ann Therese Lotherington (eds.). Transnational Marriage Migration: Russian-Norwegian Encounters. Saarbrücken: VDM Verlag.

Thue, Helge J. 2002. Internasjonal privatrett [Private International Law]. Oslo: Gyldendal Academic.

\section{Notes on contributor}

Hege Brækhus was born in Oslo in 1949. She is Cand. Jur. from the University of Oslo in 1975, Dr. Juris at the University of Tromsø in 1995 and Professor at the Faculty of Law, University of Tromsø from 2005. Her works are on women and the law, discrimination law, social security law and family law with special emphasis on legal questions in the private sphere. 